\title{
Seasonal study of sea-ice exopolymeric substances on the Mackenzie shelf: implications for transport of sea-ice bacteria and algae
}

\author{
Andrea Riedel $^{1, *}$, Christine Michel $^{2}$, Michel Gosselin ${ }^{1}$ \\ ${ }^{1}$ Institut des sciences de la mer (ISMER), Université du Québec à Rimouski, 310 allée des Ursulines, Rimouski, \\ Québec G5L 3A1, Canada
}

${ }^{2}$ Fisheries and Oceans Canada, Freshwater Institute, 501 University Crescent, Winnipeg, Manitoba R3T 2N6, Canada

\begin{abstract}
Bottom sea ice, from under high and low snow cover, and surface water samples were collected in Franklin Bay (Mackenzie shelf) on 21 occasions between 24 February and 20 June 2004 and analyzed for exopolymeric substances (EPS), particulate organic carbon (POC) and chlorophyll a (chl a). Concentrations of EPS were measured using Alcian blue staining of melted ice samples. Chl a and bacterial sinking velocities were also assessed with settling columns, to determine the potential role of EPS in the transport of sea-ice biomass. EPS concentrations in the bottom ice were consistently low in March (avg. $185 \mu \mathrm{g}$ xanthan equivalents $\mathrm{l}^{-1}$ ), after which they increased to maximum values of 4930 and $10500 \mu \mathrm{g}$ Xequiv. $\mathrm{l}^{-1}$ under high and low snow cover, respectively. EPS concentrations in the surface water were consistently 2 orders of magnitude lower than in the sea ice. Sea-ice EPS concentrations were significantly correlated with sea-ice chl a biomass $(\tau=0.70, p<0.01)$. Sea-ice algae were primarily responsible for EPS production within the sea ice, whereas bacteria produced insignificant amounts of sea-ice EPS. EPS-carbon contributed, on average, $23 \%$ of POC concentrations within the sea ice, with maximum values reaching $72 \%$ during the melt period. Median chl $a$ sinking velocities were 0.11 and $0.44 \mathrm{~m} \mathrm{~d}^{-1}$ under high and low snow cover, respectively. EPS had little effect on chl a sinking velocities. However, bacterial sinking velocities did appear to be influenced by diatom-associated and free EPS within the sea ice. Diatom-associated EPS could facilitate the attachment of bacteria to algae thereby increasing bacterial sinking velocities, whereas the sinking velocities of bacteria associated with positively buoyant, free EPS, could be reduced. EPS contributed significantly to the sea-ice carbon pool and influenced the sedimentation of sea-ice biomass, which emphasizes the important role of EPS in carbon cycling on Arctic shelves.
\end{abstract}

KEY WORDS: Exopolymeric substances $\cdot$ EPS $\cdot$ Arctic $\cdot$ Sea ice $\cdot$ Sinking velocities $\cdot$ Ice algae Bacteria $\cdot$ Settling columns $\cdot$ SETCOL

\section{INTRODUCTION}

Arctic sea ice supports a diverse community of organisms, ranging from viruses (e.g. Maranger et al. 1994, Gowing et al. 2004) to metazoans (e.g. Gradinger 1999, Nozais et al. 2001). Sea-ice algae are a major component of biomass in Arctic first-year sea ice (e.g. Smith et al. 1990, Melnikov et al. 2002) with growth being limited primarily by light and nutrient availability (e.g. Gosselin et al. 1985, Cota et al. 1987, Smith et al. 1997). Sea-ice algae are an early source of carbon for water column grazers (Michel et al. 1996, 2002) and can contribute $25 \%$ or more to total Arctic primary production (Legendre et al. 1992, Gosselin et al. 1997).

Recent studies have found high concentrations of exopolymeric substances (EPS) in Arctic sea ice (Krembs et al. 2002), with values 1 order of magnitude higher than in the surface water, during the summer and autumn (Krembs \& Engel 2001, Meiners et al. 2003). EPS encompass a diverse mixture of polysac- 
charides and glycoproteins with gel-like characteristics. They are produced by both bacteria and algae, with diatoms being the primary source of EPS in the sea ice (Meiners et al. 2003, Mancuso Nichols et al. 2004). These exopolymers can be found as thick gels around bacteria and algal cells (Myklestad 1995, Underwood et al. 1995), as free colloidal organic matter (Decho 1990, Passow 2000), or as part of large particles and aggregates (Alldredge et al. 1993, Passow et al. 2001). EPS surrounding algal cells, as well as free EPS, have been observed in Arctic and Antarctic sea ice (Krembs et al. 2002, Meiners et al. 2004). In the present study, EPS refer specifically to particulate $(>0.4 \mu \mathrm{m})$ acidic exopolysaccharides as measured by the Alcian blue method (Passow \& Alldredge 1995). The Alcian blue method was first used to measure transparent exopolymer particles (TEP), which refers primarily to discrete particles in the water column formed through the coagulation of dissolved precursors. Exopolymeric substances in the sea ice are often not discrete particles (i.e. they are cell-associated) and their formation processes are largely unknown. Therefore, the particles measured in this study will be referred to as EPS instead of TEP.

Copious amounts of EPS can be produced by benthic diatoms (Smith \& Underwood 1998) and by phytoplankton during or following the bloom period (Alldredge et al. 1993). Algal-produced EPS can help protect cells against harsh environmental conditions as well as assist in cell adhesion and motion (Cooksey \& Wigglesworth-Cooksey 1995). EPS constitute a carbon-rich substrate for bacteria, potentially supporting bacterial production and metabolic activity (Simon et al. 2002). The release of exopolymers by algae or bacteria further influences carbon cycling by (1) directly contributing to the organic carbon pool with concentrations potentially equivalent to those of particulate organic carbon (POC) in pelagic environments (Mari 1999, Engel \& Passow 2001), (2) influencing sedimentation rates through aggregation (Turner 2002, AzetsuScott \& Passow 2004), and (3) bypassing microbialmediated POC production by the abiotic formation of large EPS-containing particles or aggregates (Passow 2002a, Thornton 2002).

Sea-ice EPS have not been previously investigated on the extensive Canadian Arctic shelves. Within firstyear sea ice of the eastern Chukchi Sea, large amounts of EPS were observed surrounding algal cells, suggesting an important role in cellular protection against high salinities and low temperatures (Krembs et al. 2002). EPS can be a significant source of carbon in the sea ice, contributing 14 to $32 \%$ of integrated POC values in Arctic and Antarctic sea ice of varying ages (Meiners et al. 2003, 2004). EPS also constitute an important substrate for sea-ice bacteria (Meiners et al.
2004), potentially supporting increased microbial activity.

Our research investigated the seasonal dynamics of EPS in first-year sea ice on the Mackenzie shelf, Canadian Arctic, during an extensive winter to spring study. The general objectives of this research were to (1) evaluate EPS concentrations in bottom sea ice, under high and low snow cover, and identify relationships with sea-ice algal biomass and bacterial abundance, (2) characterize seasonal trends in EPS concentrations in the sea ice and water column and the contribution of EPS to sea-ice POC, during the complete period of seaice algae development and decline, and (3) assess the influence of EPS on the sinking velocities of sea-ice bacteria and algae. We hypothesized that EPS concentrations would be highest under low snow cover due to increased light availability for sea-ice autotrophic production (Gosselin et al. 1990) and that EPS concentrations in sea ice would increase seasonally with increasing sea-ice biomass. We also expected high concentrations of sea-ice EPS to favour aggregation and rapid sinking of sea-ice biomass.

\section{MATERIALS AND METHODS}

Routine sampling was conducted on first-year landfast ice in Franklin Bay, Northwest Territories (Fig. 1), on 21 occasions between 24 February and 20 June 2004. All samples were collected $1.5 \mathrm{~km}$ northeast of the overwintering site of the CCGS 'Amundsen' $\left(70^{\circ} 04^{\prime} \mathrm{N}, 126^{\circ} 26^{\prime} \mathrm{W}\right.$; water depth: $\sim 250 \mathrm{~m}$ ) as part of the Canadian Arctic Shelf Exchange Study (CASES). Sample analyses were conducted in laboratories on board the ship shortly after sample collection. This area was expected to have sea-ice algal biomass concentrations comparable to those in the greater Beaufort Sea region (i.e. 1 to $>30 \mathrm{mg}$ chlorophyll $a$ [chl a] $\mathrm{m}^{-2}$; Horner \& Schrader 1982, Horner 1985).

Multiple ice cores were collected with a manual ice corer (Mark II coring system, $9 \mathrm{~cm}$ internal diameter, Kovacs Enterprise) within an area of approximately $0.01 \mathrm{~km}^{2}$, with consecutive coring conducted within ca. $10 \mathrm{~m}$ of previous coring sites. On each sampling day, a total of 10 to 16 ice cores were collected at 2 sites representative of high and low snow cover to account for horizontal patchiness of sea-ice biomass (Gosselin et al. 1986, Rysgaard et al. 2001). On the 2 last sampling dates (14 and 20 June), only low snow cover sites remained due to snow melt.

At the high and low snow cover sampling sites, ice cores were collected for routine measurement of salinity, EPS, POC, chl $a$ and sinking velocities of chl $a$ and bacteria. The bottom $4 \mathrm{~cm}$ of each core was cut and put in an isothermal container. Bottom ice cores were 


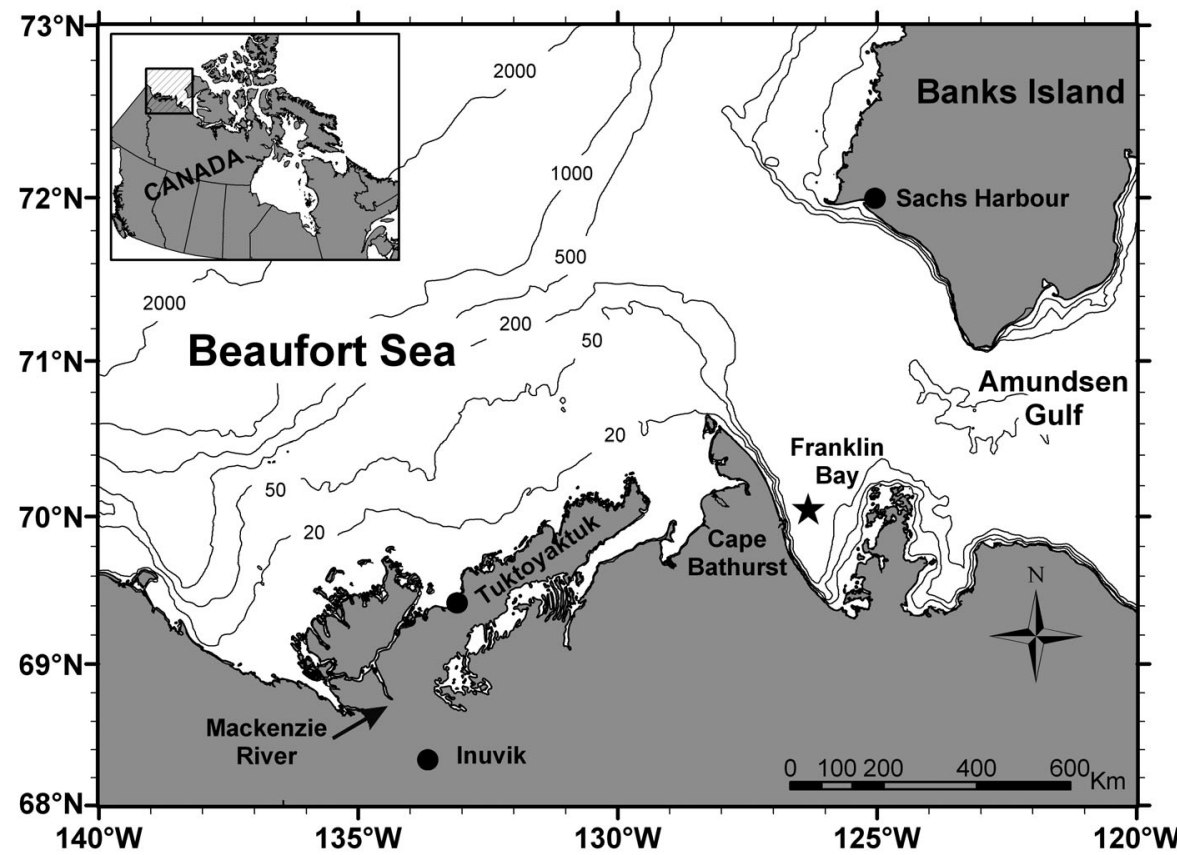

Fig. 1. Sea-ice study station on the Mackenzie shelf (Canadian Arctic), indicated by star in Franklin Bay

pooled together to obtain 1 sample for each snow cover depth. Sterile gloves were worn at all times during the manipulation of the cores. On each sampling day, water from the ice-water interface was also collected using a hand pump. A subsample of this surface water was analyzed for salinity, EPS, and chl a and another subsample was filtered on polycarbonate $0.2 \mu \mathrm{m}$ filters and added to the ice core samples to minimize osmotic stress during the melting process (Garrison \& Buck 1986). Sea-ice concentrations of all measured variables were corrected for the dilution arising from the addition of seawater during the melting process.

Sea-ice and surface water salinity were determined with an Orion salinometer. Chl $a$ and pheopigments were determined fluorometrically (10AU Turner Designs) on duplicate subsamples filtered on Whatman GF/F filters, after $24 \mathrm{~h}$ extraction in $90 \%$ acetone at $5^{\circ} \mathrm{C}$ in the dark (Parsons et al. 1984). Duplicate POC subsamples were filtered on pre-combusted Whatman $\mathrm{GF} / \mathrm{F}$ filters, stored at $-80^{\circ} \mathrm{C}$ and later analyzed with a Perkin-Elmer Model $2400 \mathrm{CHN}$ analyzer.

Triplicate EPS subsamples were filtered on $47 \mathrm{~mm}$ $0.4 \mu \mathrm{m}$ polycarbonate filters and stained with Alcian blue. EPS were measured colorimetrically $(787 \mathrm{~nm}$ ) after a $2 \mathrm{~h}$ extraction in $80 \% \mathrm{H}_{2} \mathrm{SO}_{4}$ (Passow \& Alldredge 1995). EPS concentrations were recorded as $\mu \mathrm{g}$ gum xanthan equivalents (Xequiv.) $\mathrm{l}^{-1}$ and converted to carbon equivalents according to Engel (2004).

Duplicate subsamples for bacterial counts were stained with DAPI (4,6-diamidino-2-phenylindole) at a final concentration of $1 \mu \mathrm{gl}^{-1}$ and filtered on $0.2 \mu \mathrm{m}$ black Nuclepore filters (Sherr et al. 1993). A minimum of 200 free-living bacteria was counted in 10 fields from replicate samples using epifluorescent microscopy. Bacterial carbon concentrations were estimated using a conversion factor specific to Arctic bacteria (0.03 pg C bacteria $^{-1}$; Gradinger 1999).

At the beginning of the ice algal bloom (9 April to 4 May), the sinking velocities $\left(\mathrm{m} \mathrm{d}^{-1}\right)$ of chl $a$ and bacteria from sea ice under high $(\mathrm{n}=5)$ and low $(\mathrm{n}=6)$ snow cover were estimated every 5 d using settling columns (SETCOLs), according to Bienfang (1981). These measurements did not continue throughout the decline of the sea-ice algae bloom as the ship left the overwintering location in Franklin Bay and a stable platform was no longer available. The SETCOLs consisted of a $0.47 \mathrm{~m}$ high Plexiglas cylinder equipped with ports for subsample removal at the top (0.30 l), middle (1.8 1) and bottom (0.33 l) sections of the column. The column was filled to just below the top, to avoid the attachment of sea-ice diatoms to the Plexiglas cap.

To determine sinking velocities, the bottom of 2 ice cores were melted in $2.5 \mathrm{l}$ of $0.2 \mu \mathrm{m}$ filtered surface water. Homogeneously mixed subsamples of the diluted sea ice were allowed to settle in the SETCOL for $2 \mathrm{~h}$ at $0^{\circ} \mathrm{C}$ in the dark, after which all 3 sections of the column were collected and analyzed for pigment concentration and total bacterial abundance, according to the above methods. The percentage of diatom-attached bacteria was also assessed in the settled material (bottom section) of the column by counting the number of diatom-attached and freeliving bacteria in an additional 10 fields.

Sinking velocities (SV) were calculated according to:

$$
\mathrm{SV}=\left(B_{\mathrm{S}} / B_{\mathrm{t}}\right) \times 1 / t
$$

where $B_{\mathrm{s}}$ is the settled biomass in the bottom section of the column, $B_{\mathrm{t}}$ is the total biomass, $l$ is the SETCOL height and $t$ is the settling period in days (Bienfang 1981). Negative sinking velocities indicate the presence of buoyant biomass. The replicability of SETCOL trials were tested on sea-ice subsamples collected on 3 May; the coefficients of variation of 2 replicate trials for chl $a$ and bacterial sinking velocities were 0.98 and $11.5 \%$, respectively.

The data were analyzed with nonparametric rank statistics (Sokal \& Rohlf 1995). Wilcoxon's signed-ranks tests 


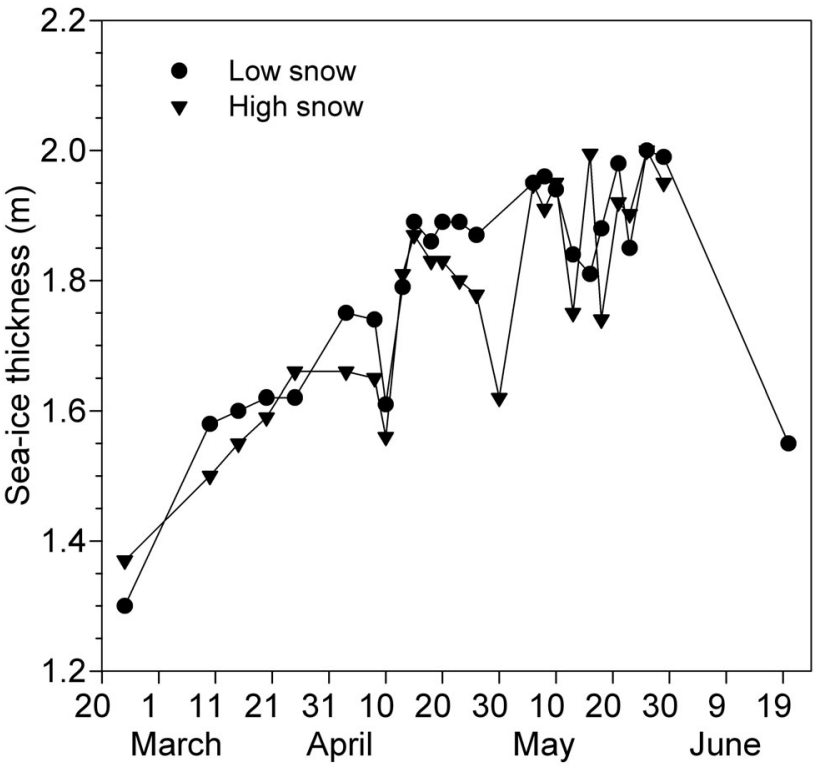

Fig. 2. Seasonal trend in sea-ice thickness, at high and low snow cover sampling sites, from February to June 2004 were used to compare paired variates from the high and low snow cover sites and from the SETCOLs. Kendall's coefficient of rank correlation $(\tau)$ was computed to infer the relationship between 2 variables. Statistical tests were performed with JMP (SAS Institute).

\section{RESULTS}

\section{Spatial and seasonal trends}

In Franklin Bay, sea-ice thickness increased from $1.3 \mathrm{~m}$ to a maximum of $2.0 \mathrm{~m}$ during the sampling period (Fig. 2). A significant decrease in ice thickness began in early June, coinciding with the appearance of melt ponds. Seasonally averaged snow depth at the high and low snow cover sites was $16.2 \pm 3.5$ and $3.4 \pm$ $2.5 \mathrm{~cm}$, respectively. On the last 2 sampling dates (14 and 20 June, Fig. 3) there were no high snow sites remaining for sampling due to the spring snow melt. Salinity averaged 9.5 (range 5.9 to 12.8) and 29.7

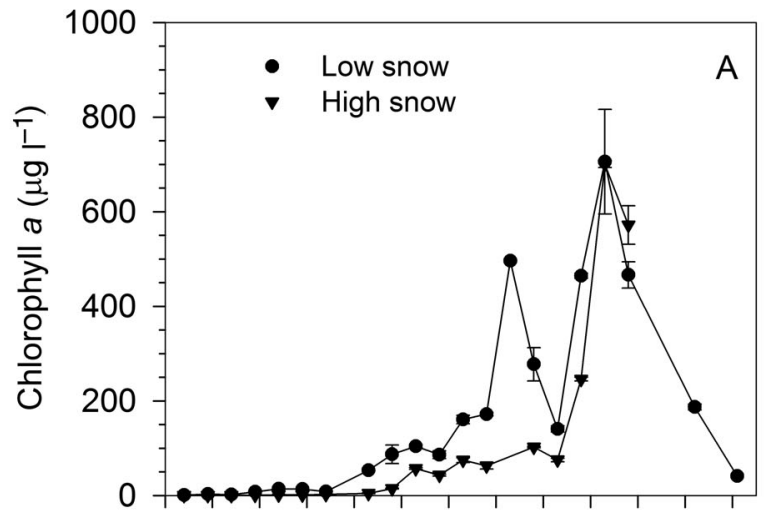

$2011112131102030102030 \quad 9 \quad 19$

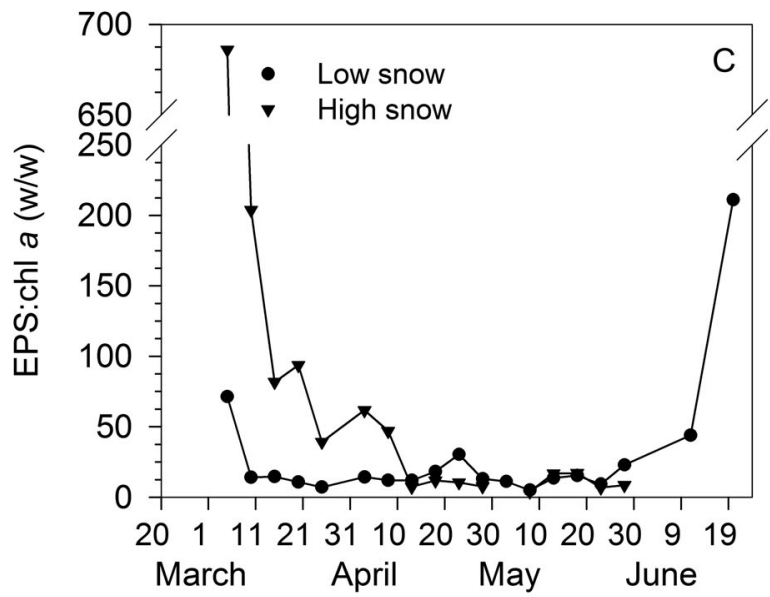

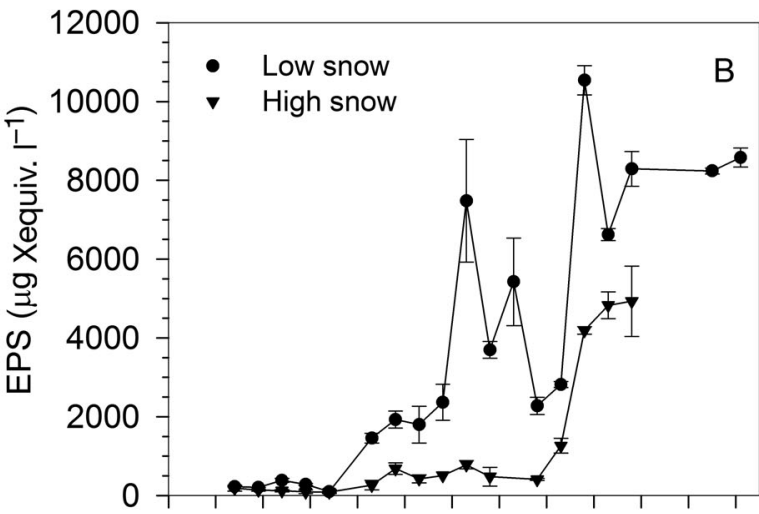

$2011112131102030102030 \quad 9 \quad 19$

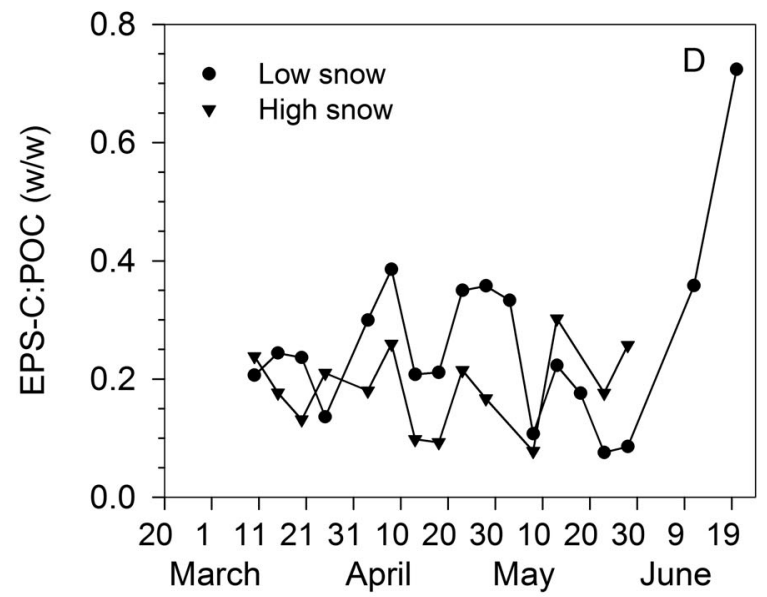

Fig. 3. Seasonal trends in the concentration of (A) sea-ice chl a and (B) sea-ice exopolymeric substances (EPS), and in sea-ice ratios of (C) EPS:chl $a$ and (D) EPS-carbon:POC (EPS-C:POC) under high and low snow cover from February to June 2004. 
(range 5.4 to 34.4 ) in the sea ice and surface water, respectively. Sea-ice salinity remained relatively constant throughout the sampling period. In the surface water there was a rapid decline in salinity during the melt period with values decreasing from 31.0 to 5.4 between 29 May and 20 June (data not shown).

The low snow cover site consistently showed higher bottom sea-ice chl a concentrations than the high snow site (except on 28 May, Fig. 3A). From February to April, bottom sea-ice chl a concentrations under low snow cover were, on average, 5.5 times higher than values under high snow cover. This difference dropped to ca. 2 from May to June (Fig. 3A, Table 1). In the surface water, chl a concentrations remained below $1 \mu \mathrm{g} \mathrm{l}^{-1}$, about 3 orders of magnitude lower than in the sea ice, for the entire sampling period (Fig. 4A). Maximum bacterial abundance also occurred under low snow cover (Table 1). However, bacterial abundance under high and low snow cover showed similar seasonal increases with median abundance increasing by 40 and $43 \%$ under high and low snow cover, respectively, between the February to April and May to June periods (Table 1).

EPS concentrations in the bottom sea ice were consistently low during the month of March (high snow: $128 \pm 40 \mu$ g Xequiv. $1^{-1}$; low snow: $241 \pm 105 \mu \mathrm{g}$ Xequiv. $\mathrm{l}^{-1}$ ). Thereafter, EPS concentrations increased, reaching maximum values of 4930 and $10500 \mu g$ Xequiv. $\mathrm{l}^{-1}$ under high and low snow cover, respectively (Fig. 3B). Maximum EPS concentrations in the bottom ice were observed on 18 and 28 May at the low and high snow sampling sites, respectively. EPS concentrations in the surface water were 2 orders of magnitude lower than those measured in the bottom sea ice, ranging from below detection to a maximum of $80 \mu \mathrm{g}$ Xequiv. $\mathrm{l}^{-1}$ (Fig. 4B). Mid-way through the sampling period (23 to 28 April), EPS concentrations in the surface water dropped to values below detection. This trend was not observed within the sea ice under high or low snow cover.

Under high and low snow cover, sea-ice EPS:chl $a$ ratios $(\mathrm{w} / \mathrm{w})$ ranged between 4.0 and 685 and between 5.0 and 211, respectively (Fig. 3C, Table 1). The maximum EPS:chl a ratio under high snow cover was observed at the very beginning of the sampling period (5 March, Fig. 3C). In comparison, the maximum EPS:chl a ratio under low snow cover was observed on the last sampling date (20 June) during the melt period. The EPS:chl a ratios were similar under both snow cover areas during the period of ice algal growth (Fig. 3). However EPS:chl a ratios were significantly higher (Wilcoxon's, p < 0.01) under high compared to low snow cover during the first part of the season (5 March to 8 April, Fig. 3C, Table 1). In the surface water, the median EPS:chl a ratio was 81.6, with values ranging between 0 and 456 (Fig. $4 \mathrm{C})$. Wilcoxon's signed-ranks tests indicated that this ratio was significantly higher $(\mathrm{p} \leq 0.05)$ in the surface water than in the sea ice under low snow cover but not significantly different $(p=0.27)$ under high snow cover.

Estimated EPS-carbon ranged from 57.4 to 3110 and 64.0 to $6640 \mu \mathrm{g} \mathrm{C}^{-1}$ in the sea ice under high and low snow cover, respectively (Table 1) and

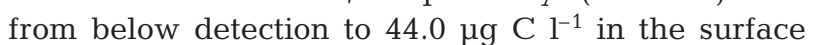
water (data not shown). EPS-carbon:POC ratios were variable in the sea ice and no clear seasonal trends were observed except for large increases on the last 2 sampling dates, with values increasing to 0.36 and 0.72 on 14 and 20 June, respectively (Fig. 3D). These increases paralleled increases in the EPS:chl a ratios on the same dates (Fig. 3C). The median EPS-carbon:POC ratio was lower under high snow compared to low snow cover during February to April (Wilcoxon's, $p<0.05$ ), whereas it was similar under both snow covers during May and June (Wilcoxon's, $\mathrm{p}=0.7$, Table 1).

EPS concentrations in the surface water were not significantly correlated with surface or sea-ice chl a concentrations (Figs. 3A \& 4A,B). However, sea-ice EPS concentrations were significantly correlated with sea-ice chl $a$ 

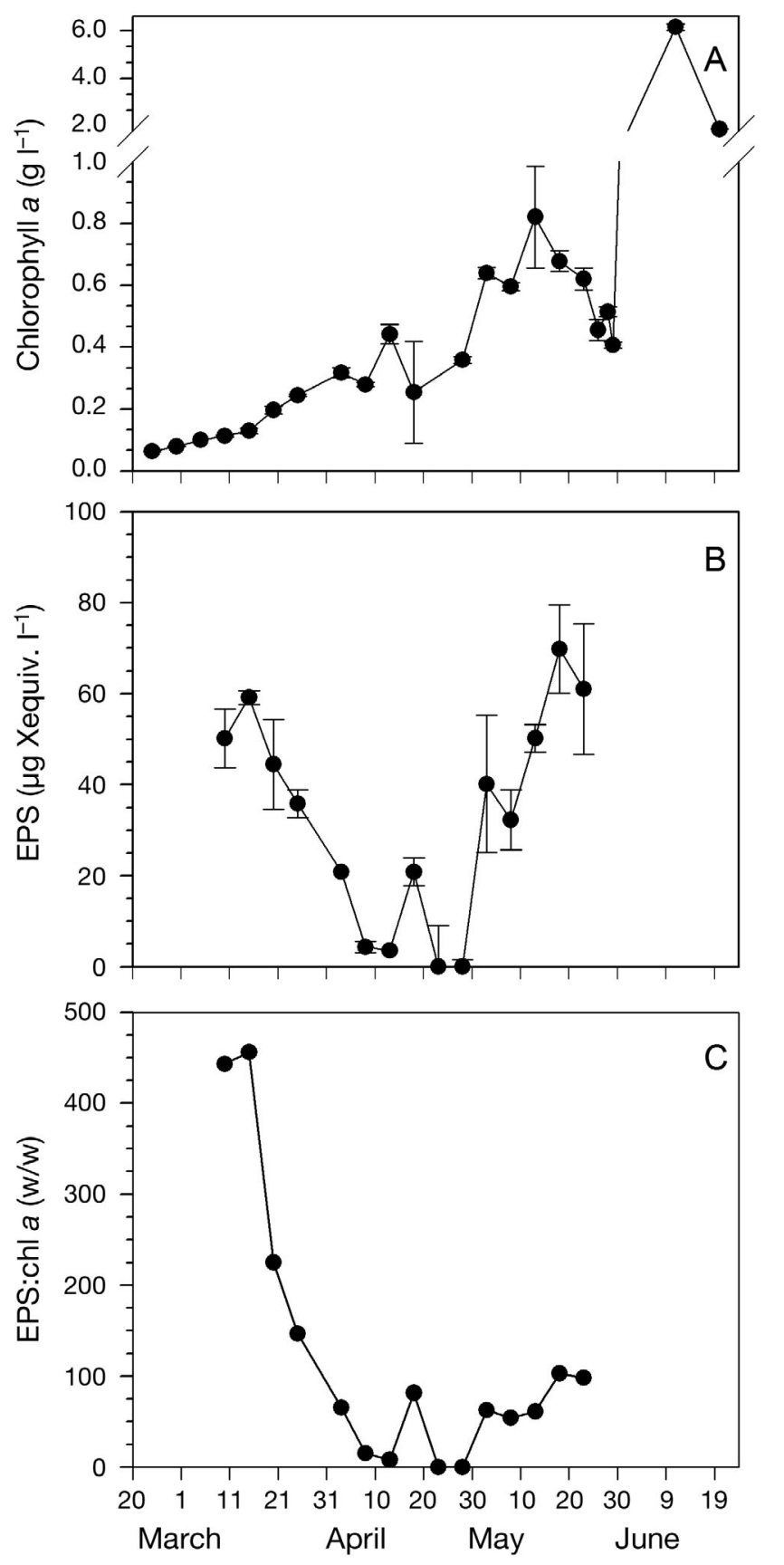

Fig. 4. Seasonal trends in concentration of (A) chl a and (B) exopolymeric substances (EPS), and in (C) EPS:chl a ratios in surface waters from February to June 2004. In (A) and (B), means $\pm \mathrm{SD}$ are shown

under high $(\tau=0.65, \mathrm{p}<0.01$, Fig. 5A) and low $(\tau=$ $0.70, p<0.01$, Fig. 5B) snow cover. The positive correlation under high snow cover (Fig. 5A) was driven primarily by parallel increases in both EPS and chl a concentrations at the end of the sampling period (18 to 28 May, Fig. 3A,B).
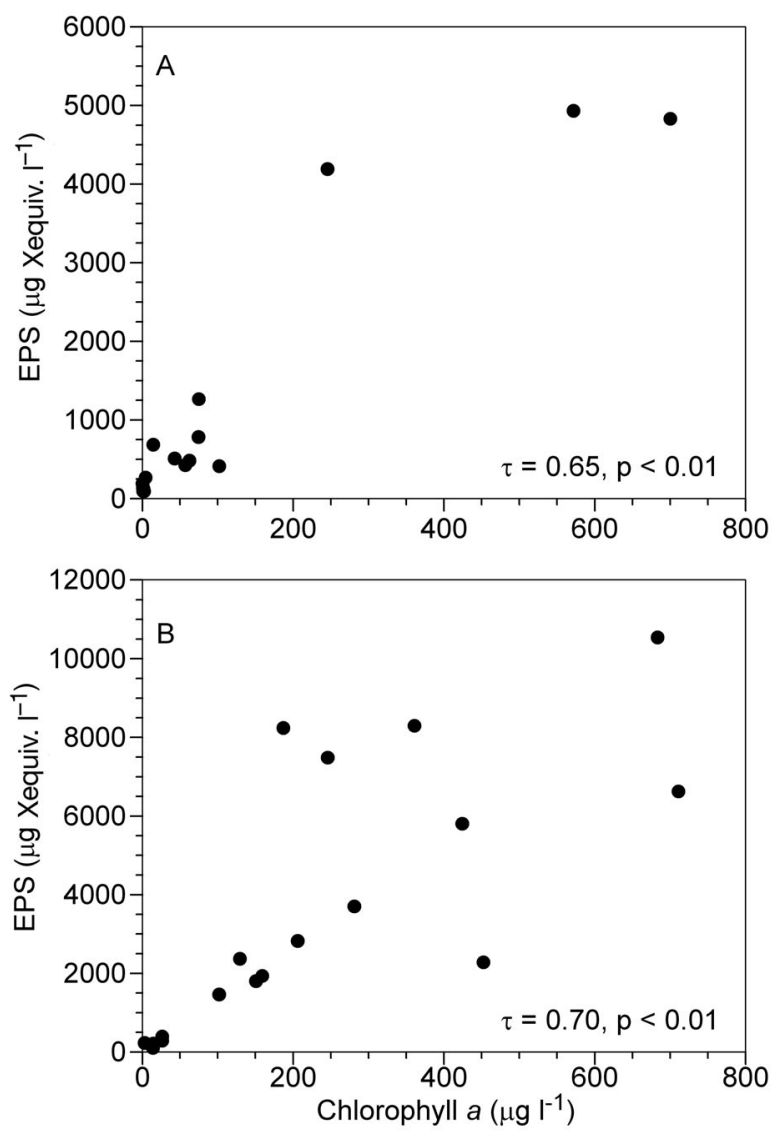

Fig. 5. Correlations between sea-ice exopolymeric substances (EPS) and chl a concentrations under (A) high and (B) low snow cover

\section{Sinking velocities}

During this study, chl a was the main pigment in the bottom section (i.e. settled pigments) of the SETCOLs. It accounted for $91 \pm 10$ and $89 \pm 11 \%$ of the total (i.e. chl $a+$ pheopigments) settled pigments in sea ice collected under high and low snow cover, respectively. The sinking velocities of total pigments and chl a sinking velocities were not significantly different under high (Wilcoxon's, $\mathrm{p}=0.53$ ) or low (Wilcoxon's, $\mathrm{p}=0.75$ ) snow cover.

Table 2 summarizes chl a sinking velocities estimated from the SETCOLs. Chl a sinking velocities varied throughout the study with a general increasing trend following 14 April, under high snow cover. Chl a sinking velocities were consistently higher for samples collected under low snow than under high snow (Wilcoxon's, $\mathrm{p}<0.05$ ), with median values of 0.11 and $0.44 \mathrm{~m} \mathrm{~d}^{-1}$ under high and low snow, respectively. No clear relationships were observed between chl a sinking velocities and chl $a$ or EPS concentrations under high or low snow cover. 
Table 2. Sinking velocities of chl $a$ and bacteria from sea ice under high and low snow cover and the percentage of diatom-attached bacteria in the settled material of the settling columns. Median and range values are given; sample size in parentheses. One chl a sinking velocity (14 April) was excluded due to erroneous initial chl a measurements

\begin{tabular}{|ccc|}
\hline \multicolumn{2}{|c|}{$\begin{array}{c}\text { Sinking velocity }\left(\mathrm{m} \mathrm{d}^{-1}\right) \\
\text { Bhl } a\end{array}$} & $\begin{array}{c}\text { Diatom-attached } \\
\text { bacteria }(\%)\end{array}$ \\
\hline High snow & & \\
$0.11(4)$ & $-0.12(5)$ & $0.9(5)$ \\
-0.03 to 0.41 & -0.25 to 0.41 & 0 to 17.6 \\
Low snow & $0.03(6)$ & $19.8(6)$ \\
$0.44(5)$ & -0.17 to 0.32 & 8.0 to 30.3 \\
0.24 to 0.68 & & \\
\hline
\end{tabular}

Sinking velocities of total bacteria ranged between -0.25 and $0.41 \mathrm{~m} \mathrm{~d}^{-1}$ and between -0.17 and $0.32 \mathrm{~m}$ $\mathrm{d}^{-1}$, under high and low snow cover, respectively (Table 2). Diatom-attached bacteria were observed in the settled material of all SETCOLs from the low snow cover site (median: $20 \%$ of total bacteria, range: 8 to $30 \%$ ), and in 4 of the 5 SETCOLs from the high snow cover site (median: $9 \%$ of total bacteria, range: 0 to $18 \%$, Table 2). Bacterial sinking velocities were significantly correlated with the percent diatom-attached bacteria under low snow cover $(\tau=0.80, \mathrm{p}<0.05$, Fig. 6) whereas there was no correlation between these 2 variables under high snow cover.

We hypothesized that increases in sea-ice EPS concentration and percent diatom-attached bacteria could enhance bacterial sinking velocities. An increase in sea-ice EPS concentrations was also expected to enhance the percentage of diatom-attached bacteria. Correlation analysis was used to test these relationships for high and low snow sites combined. Bacterial sinking velocities were only significantly correlated with the percentage of diatom-attached bacteria $(\tau=$ 0.54, $\mathrm{p}<0.05)$. Bacterial sinking velocities were not correlated with free-living bacterial abundance $(\tau=$ $0.36, p=0.15)$ or sea-ice EPS concentrations $(\tau=0.09, p$ $=0.72$ ). In addition, during the period of SETCOL measurements, EPS concentrations were not correlated with the percentage of diatom-attached bacteria $(\tau=$ $0.38, \mathrm{p}=0.10)$.

\section{DISCUSSION}

In pelagic systems, exopolymeric substances in the form of TEP have been recognized as a key component of the carbon cycle, directly contributing to the carbon pool and influencing sedimentation and small-scale microbial processes such as nutrient uptake and bacterial productivity (see Passow 2002a). Previous studies of first-year pack ice in Antarctica (Meiners et al. 2004) and first-year, landfast and pack ice in the Arctic (Krembs \& Engle 2001, Krembs et al. 2002, Meiners et al. 2003) have found high concentrations of EPS in the interior and bottom of the sea ice. The current study found EPS to be a significant contributor to sea-ice carbon on Canadian Arctic shelves, with concentrations reflecting spatial and temporal variations in the sea-ice community. Key relationships were identified between EPS, chl a and bacteria, showing that EPS can influence carbon cycling within the sea ice and upon the release of sea-ice biomass into the water column at the time of ice melt.

\section{Producers of EPS in sea ice}

During our study, sea-ice EPS concentrations were on average three times lower under high snow than low snow cover. Still, EPS concentrations under high snow cover were 2 orders of magnitude higher than in the surface water. It is apparent that the sea ice of the Mackenzie shelf contains substantial amounts of EPS, with the maximum EPS concentration measured during our study $\left(10500 \mu \mathrm{g}\right.$ Xequiv. $\mathrm{l}^{-1}$ under low snow) surpassing the highest concentration of EPS previously reported in first-year Arctic sea ice (7710 $\mu \mathrm{g}$ Xequiv. $\mathrm{l}^{-1}$, Krembs et al. 2002). We may have slightly overestimated sea-ice EPS concentrations due to reassembly of EPS from the addition of $0.2 \mu \mathrm{m}$ filtered water during the melting process. However, this source of EPS would be minimal due to the very low EPS concentrations in surface waters (Fig. 4B).

$\mathrm{Chl}$ a concentrations in the bottom sea ice were consistently lower under high snow compared to low snow cover, suggesting that light limitation did influence sea-ice algal growth under high snow cover. The spatial (i.e. high snow vs. low snow) and seasonal trends in EPS and chl a concentrations were very similar (Fig. 3A,B), reflecting the significant correlation between EPS and chl a concentrations (Fig. 5).

The significant correlations between EPS and chl a concentrations under high and low snow cover (Fig. 5) indicate that sea-ice algae were primarily responsible for the production of EPS in the sea ice. EPS concentrations in pack ice of the Laptev Sea (Krembs \& Engel 2001) and Fram Strait (Meiners et al. 2003) were also significantly correlated with chl $a$ and diatom abundances. Pennate diatoms of the genus Nitzschia have been found to be the most important producers of EPS within sea ice (Krembs \& Engel 2001, Meiners et al. 2003). Pennate diatoms of the genera Nitzschia and Navicula were a dominant component of the ice algal communities during our study. However, species composition and form (i.e. solitary cells vs. colonies) varied 
between high and low snow cover sites (M. Różańska pers. comm.). Such variation in species composition and form could contribute to the spatial variation in sea-ice EPS concentrations on the Mackenzie shelf. Laboratory experiments have shown that the production of exopolysaccharides varies widely among marine algal species, both in amount and chemical structure (Myklestad 1995, Passow 2002b), and is dependent upon their growth rates (Waite et al. 1995).

Bacteria can also be important producers of EPS (Mancuso Nichols et al. 2005). Bacteria isolates from Antarctic sea ice were found to produce EPS, with highest yields at lower temperatures (i.e. -2 to $10^{\circ} \mathrm{C}$, Mancuso Nichols et al. 2004). Pelagic bacteria also produce exopolymers but in low amounts relative to algal exopolymer production (Schuster \& Herndl 1995, Passow 2002b), and the cell-specific production rate has been estimated to be only 4 amol C cell ${ }^{-1} \mathrm{~d}^{-1}$ (Stoderegger \& Herndl 1999). Using this pelagic production rate for bacterial exopolymers, Meiners et al. (2004) estimated that total bacterial production of EPS $\left(2.5 \mu \mathrm{g} \mathrm{Cl}^{-1} \mathrm{~d}^{-1}\right)$ was 2 orders of magnitude lower than their estimated algal EPS production $\left(195 \mathrm{\mu g} \mathrm{C}^{-1} \mathrm{~d}^{-1}\right)$ in Antarctic pack ice. We estimated total sea-ice bacterial production of EPS to be, on average, $0.1 \mu \mathrm{g} \mathrm{Cl}^{-1} \mathrm{~d}^{-1}$ during the beginning of the ice algal bloom, also using the production factor of Stoderegger \& Herndl (1999). When corrected for low temperatures within the sea ice, our estimate could be as high as $3 \mu \mathrm{g} \mathrm{C} \mathrm{l}^{-1} \mathrm{~d}^{-1}$. Thus, our estimates of EPS production by sea-ice bacteria are orders of magnitude lower than the average concentration of sea-ice EPS-carbon $\left(1600 \mu \mathrm{g} \mathrm{C} \mathrm{l}^{-1}\right)$ during the same period, showing that sea-ice bacteria are not important contributors of sea-ice EPS. These results strongly suggest that EPS were produced primarily by algae, with a potentially minor contribution from bacteria, within the sea ice of the Mackenzie shelf.

Estimates of EPS-carbon in the bottom sea ice had a median value of $857 \mathrm{\mu g} \mathrm{Cl}^{-1}$ and ranged from 57.4 to $6640 \mu \mathrm{g} \mathrm{Cl}^{-1}$. While these values represent an approximation of sea-ice EPS-carbon, as the conversion factor was derived from laboratory experiments of TEP originating from diatoms only (Engel 2004), they indicate that EPS can contribute, on average, $22.8 \%$ (range 21.7 to $23.9 \%$ ) of the bottom ice POC on the Mackenzie shelf. In comparison, sea-ice bacterial carbon contributed, on average, $2.3 \%$ of bottom ice POC in our study. Our values for the contribution of EPS-carbon to POC could be overestimated due to differences in filtration pore size (EPS is filtered on $0.4 \mu \mathrm{m}$ polycarbonate membrane, whereas POC is filtered on glass-fiber filter with a nominal porosity of $0.7 \mu \mathrm{m})$. However, our results are similar to results from the pack ice in Fram Strait, where EPS-carbon was estimated to account for
$24 \%$ of sea-ice POC (Meiners et al. 2003). This indicates that EPS represents a widespread source of carbon in Arctic sea ice. In the context of Arctic climate warming, sea ice reduction may thus impinge on the roles of EPS in carbon cycling and food web dynamics (e.g. Salcher et al. 2005) in sea ice.

\section{EPS seasonal dynamics}

Sea ice

Our study began in February, well before the development of the ice algal bloom, and extended throughout the bloom and its termination, the latter evidenced by the rapid decrease in sea-ice chl $a$ at the end of the sampling period (28 May to 20 June, Fig. 3A). In this study, sea-ice EPS concentrations remained low (ca. $185 \mu \mathrm{g}$ Xequiv. $\mathrm{l}^{-1}$ ) until April, as compared to sea-ice concentrations $>1000 \mu \mathrm{gg}$ Xequiv. $\mathrm{l}^{-1}$ found in early March near Barrow, Alaska (Krembs et al. 2002).

Sea-ice EPS concentrations increased seasonally, following the trend in sea-ice algal biomass ( $\mathrm{chl} a$ ). However, sea-ice EPS and chl a concentrations became decoupled at the end of the season when we observed a rapid decline in chl a concentrations, but stable and high EPS concentrations (Fig. 3A,B). Consequently, the sea-ice EPS:chl a ratios greatly increased upon the termination of the ice algal bloom (Fig. 3C). Concurrently, the EPS-carbon:POC ratio rapidly increased, with EPS-carbon accounting for a maximum of $72 \%$ of sea-ice POC on 20 June. This suggests that algal biomass and associated POC were released from the sea ice at a faster rate than EPS. A corollary to this is that not all EPS were attached to particles within the sea ice, and that free EPS would remain longer in the sea ice than particle-attached EPS.

Alternatively, if EPS were exported from the sea ice at the same rate as particulate organic material, the high EPS:chl $a$ and EPS-carbon:POC ratios observed at the end of the season would only be explained by increased in situ EPS production. Under-ice sediment traps adjacent to our sampling station confirmed that sea-ice algae, which were mainly diatoms at the peak of the sea-ice algal bloom, were being released from the sea ice at the time of ice melt ( $T$. Juul-Pedersen pers. comm.). This confirms that the low sea-ice chl $a$ concentrations observed at the end of season represented a reduced abundance of diatoms rather than a decrease in the chl a content of algal cells. Assuming limited EPS production by bacteria, as previously discussed, the remaining algal community on the last sampling day would have had to increase EPS production by, on average, 15-fold to produce the observed EPS concentration. Such increases in EPS production 
are unlikely. Increases of only 1.5 - to 5 -fold in diatom extracellular carbohydrate production have been reported due to nutrient or environmental stress (Urbani et al. 2005, Abdullahi et al. 2006). Therefore, we conclude that increased in situ production of EPS did not likely explain the high EPS-carbon:POC and EPS:chl a ratios observed at the end of the sampling period, suggesting that free EPS were retained within the melting sea ice. EPS retained in the sea ice could supply a pulse of organic carbon to surface waters after the majority of sea-ice biomass has been released into the water column.

\section{Surface waters}

Seasonal EPS dynamics in surface waters did not follow the same trend as those in the sea ice. In March, surface EPS concentrations declined as surface chl a concentrations increased (Fig. 4A,B). In April, EPS concentrations fell to below detection (23 to 28 April) and then concurrently increased with increasing surface chl a concentrations during the sea-ice algal bloom period.

The average EPS:chl a ratio in surface waters was over 2 times higher than in the sea ice (i.e. 140 vs. 58). The surface EPS:chl a ratios in our study were similar to TEP:chl a ratios found during a spring phytoplankton bloom in the subarctic Pacific (max. 120 to 190, Ramaiah et al. 2001) and surpassed TEP:chl a ratios from the Ross Sea (avg. 85, Hong et al. 1997) and Atlantic Ocean (avg. 49 to 104, Engel 2004). It is possible that, in our study, phytoplankton produced high amounts of EPS due to light limitation and/or low water temperatures. However, the decoupling of surface EPS and chl a concentrations, as well as the increasing surface EPS:chl a ratios during the sea-ice algal bloom, suggest that surface EPS may have been supplemented with sea-ice EPS.

If EPS were released from the sea ice during the sampling period, then EPS did not accumulate at high concentrations in surface waters. EPS released to the surface waters may have been quickly degraded by biological or physical processes. Alternatively, any EPS entering or produced within the surface waters may be advected (Krembs \& Engel 2001) or sink, thereby influencing the downward export of sea-ice and water column carbon.

\section{Biogeochemical roles of EPS in sea ice}

We hypothesized that high concentrations of EPS in the sea ice would enhance the sinking velocities of sea-ice biomass. However, EPS were not significantly correlated with chl a sinking velocities in the sea ice of the Mackenzie shelf. Chl a sinking velocities measured during this study were within the lower range of expected sinking rates for individual phytoplankton cells ( $<1$ to $10 \mathrm{~m} \mathrm{~d}^{-1}$; Culver \& Smith 1989) and 2 to 3 orders of magnitude lower than those measured for diatom-containing, marine snow aggregates (16 to $368 \mathrm{~m} \mathrm{~d}^{-1}$; Turner 2002). Therefore, despite very high concentrations of EPS within the sea ice of the Mackenzie shelf, EPS did not appear to favour the formation of aggregates within the sea ice, which would sink at high rates once released into the water column.

The sea ice on the Mackenzie shelf would be expected to contain both free and particle-attached EPS, similar to observations of other Arctic first-year sea ice (Krembs et al. 2002). During the SETCOL measurements, all forms of EPS would have been released from the sea ice into a dilute, turbulence-free environment. Our low sinking velocities suggest the absence of large aggregate formation within the sea ice and the absence of spontaneous aggregation of EPS and algal cells, under non-turbulent conditions. The absence of wind-induced mixing of the surface waters due to ice cover may also have limited aggregate formation in Franklin Bay. However, currents and/or shear at the ice-water interface could enhance aggregate formation after EPS is released from the sea ice. We thus conclude that EPS from the sea ice of the Mackenzie shelf does not directly enhance the sinking rate of sea-ice algae released to the water column.

Bacterial sinking velocities were hypothesized to be positively related to bacterial abundances, EPS concentrations and bacterial attachment to sea-ice diatoms. Our results show that bacterial sinking velocities did increase with increased percentage of attached bacteria, but were not significantly correlated with the abundance of free-living bacteria. Also, contrary to our hypothesis, there was no direct correlation between EPS concentrations and bacterial sinking velocities. However, EPS may facilitate the attachment of bacteria to sea-ice diatoms and could be involved in the upward transport of sea-ice bacteria.

In Antarctic sea ice, $100 \%$ of free EPS were observed to be colonized by bacteria (Meiners et al. 2004). Bacteria may utilize this free EPS as a site of attachment, possibly protecting them from grazers (Salcher et al. 2005), or as a carbon-rich substrate which could enhance bacterial production. Similar levels of colonization by bacteria have been observed for TEP in the water column (Passow \& Alldredge 1994). These discrete particles of exopolymeric substances have been observed to be positively buoyant and the direction of transport for cells associated with these particles was dependent on the relative proportions of solid matter, interstitial water and exopolymers (Azetsu-Scott \& 
Passow 2004). These exopolymers could ascend in association with attached bacteria and/or larger organic or inorganic particles that would sink in their absence (Azetsu-Scott \& Passow 2004).

Negative bacterial sinking velocities were observed in our SETCOLs under high and low snow cover. The negative sinking velocities suggest that at least a portion of the bacterial community was positively buoyant. The majority of free-living, sea-ice bacteria in this study were small ( $\leq 1 \mu \mathrm{m}$ long) and would not have moved significantly through the water column on their own. Therefore, any upward transport of bacteria was likely due to buoyant EPS in association with freeliving bacteria. Under high snow cover, $60 \%$ of the bacterial sinking velocities were negative and the negative sinking velocities increased with increasing sea-ice EPS concentrations. It thus appears that, irrespective of snow cover, free EPS may enhance the ascent of free-living bacteria.

Bacterial sinking velocities also appeared to be influenced by diatom-associated EPS. Under low snow cover only, bacterial sinking velocities significantly increased with the proportion of bacteria attached to diatoms (Fig. 6). Our results suggest that bacterial attachment to diatoms could be favoured by EPS surrounding algal cells, as indicated by the positive relationship between EPS concentrations and the proportion of diatom-attached bacteria. It is not known why a higher percent of diatom-attached bacteria was found under low snow cover, thus having a greater influence on bacterial sinking velocities. Both bacterial abundances and EPS concentrations were within the same

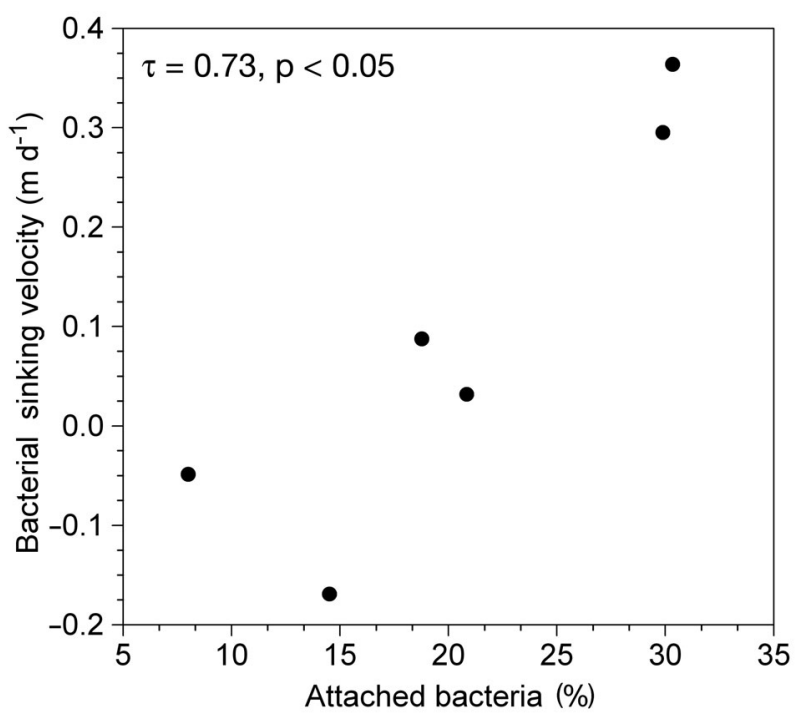

Fig. 6. Correlation between bacterial sinking velocity and percentage of diatom-attached bacteria in the settled material of the settling columns from sea-ice samples collected under low snow cover range under high and low snow cover during the SETCOL measurements. However, algal speciesspecific differences between snow cover sites may have altered the form of sea-ice EPS produced (Myklestad 1995), thereby influencing bacteria-EPS interactions.

\section{CONCLUSIONS}

This study represents the most complete seasonal study of EPS in Arctic sea ice to date. For the first time, EPS concentrations under variable snow cover conditions were assessed, showing local spatial variations in addition to seasonal changes in EPS concentrations. We found that the roles of EPS under high snow cover may represent winter and early spring dynamics of sea-ice EPS in general, with more complex interactions occurring only after sufficiently high concentrations of EPS and algal biomass develop within the sea ice. EPS contributed significantly to the sea-ice carbon pool, with EPS-carbon contributing up to $72 \%$ of sea-ice POC during the melt period. High EPS-carbon:POC and EPS:chl a ratios during the melt period indicated that EPS can be retained within the sea ice whereas sea-ice algae and other particulate carbon sources are more easily released to the water column during the melt period.

High concentrations of EPS within the sea ice, under high or low snow cover, had very little effect on the downward transport of sea-ice algae when released into dilute, turbulent-free conditions of the SETCOLs. Despite EPS concentrations 2 orders of magnitude higher than the surface water, we found no evidence indicating the formation of rapidly sinking aggregates within the sea ice. EPS did appear to influence the upward and downward transport of sea-ice bacteria. The buoyant properties of EPS could have enhanced the upward transport of free-living bacteria resulting in negative sinking velocities, while EPS also appeared to mediate the attachment of bacteria to sea-ice diatoms, thereby increasing their sinking velocities. This study has shown that EPS not only contributes directly to the carbon pool in first-year sea ice, but also influences carbon cycling within the sea ice and the fate of sea-ice carbon once released to the water column.

Acknowledgements. We sincerely thank the officers and crew of the CCGS 'Amundsen' for their support of this research expedition. B. LeBlanc, T. Juul-Pedersen, M. Różańska, A. Tatarek, J. Wiktor, M. Lizotte, M. Poulin and other collaborators assisted in the field and laboratory during the expedition. D. Bérubé and M. Simard conducted the POC analyses. We also thank 3 anonymous reviewers for their constructive comments on the manuscript. This project was supported by grants from the Natural Sciences and Engineering Research 
Council (NSERC) of Canada (Research Network grant to C.M. and M.G.; individual and Northern Research Supplement Discovery grants to M.G.) and from the Department of Fisheries and Oceans (DFO) Academic Science Subvention Program to M.G. and C.M., and by financial support from the DFO Science Strategic Fund to C.M. Partial operating funds for the CCGS 'Amundsen' were provided by the International Joint Ventures Fund of the Canada Foundation for Innovation and the Fonds québécois de la recherche sur la nature et les technologies (FQRNT). A.R. received post-graduate scholarships from NSERC, UQAR, the Fondation de l'UQAR and the Institut des sciences de la mer de Rimouski (ISMER), and financial support from Indian and Northern Affairs Canada for fieldwork. This is a contribution to the research programs the Canadian Arctic Shelf Exchange Study (CASES), the Freshwater Institute (Fisheries and Oceans Canada), ISMER and Québec-Océan.

\section{LITERATURE CITED}

Abdullahi AS, Underwood GJC, Gretz MR (2006) Extracellular matrix assembly in diatoms (Bacillariophyceae). V. Environmental effects on polysaccharide synthesis in the model diatom, Phaeodactylum tricornutum. J Phycol 42: 363-378

Alldredge AL, Passow U, Logan BE (1993) The abundance and significance of a class of large, transparent organic particles in the ocean. Deep-Sea Res I 40:1131-1140

Azetsu-Scott K, Passow U (2004) Ascending marine particles: significance of transparent exopolymer particles (TEP) in the upper ocean. Limnol Oceanogr 49:741-748

Bienfang PK (1981) SETCOL - a technologically simple and reliable method for measuring phytoplankton sinking rates. Can J Fish Aquat Sci 38:1289-1294

Cooksey KE, Wigglesworth-Cooksey B (1995) Adhesion of bacteria and diatoms to surfaces in the sea: a review. Aquat Microb Ecol 9:87-96

Cota GF, Prinsenberg SJ, Bennett EB, Loder JW, Lewis MR, Anning JL, Watson NHF, Harris LR (1987) Nutrient fluxes during extended blooms of arctic ice algae. J Geophys Res 92:1951-1962

Culver ME, Smith WO Jr (1989) Effects of environmental variation on sinking rates of marine phytoplankton. J Phycol 25:262-270

Decho A (1990) Microbial exopolymer secretions in ocean environments: their role(s) in food webs and marine processes. Oceanogr Mar Biol Annu Rev 28:73-153

Engel A (2004) Distribution of transparent exopolymer particles (TEP) in the northeast Atlantic Ocean and their potential significance for aggregation processes. Deep-Sea Res I 51:83-92

Engel A, Passow U (2001) Carbon and nitrogen content of transparent exopolymer particles (TEP) in relation to their Alcian blue adsorption. Mar Ecol Prog Ser 219:1-10

Garrison DL, Buck KR (1986) Organism losses during ice melting: a serious bias in sea ice community studies. Polar Biol 6:237-239

Gosselin M, Legendre L, Demers S, Ingram RG (1985) Responses of sea-ice microalgae to climatic and fortnightly tidal energy inputs (Manitounuk Sound, Hudson Bay). Can J Fish Aquat Sci 42:999-1006

Gosselin M, Legendre L, Therriault JC, Demers S, Rochet M (1986) Physical control of the horizontal patchiness of seaice microalgae. Mar Ecol Prog Ser 29:289-298

Gosselin M, Legendre L, Therriault JC, Demers S (1990) Light and nutrient limitation of sea-ice microalgae (Hudson Bay,
Canadian Arctic). J Phycol 26:220-232

Gosselin M, Levasseur M, Wheeler PA, Horner RA, Booth BC (1997) New measurements of phytoplankton and ice algal production in the Arctic Ocean. Deep-Sea Res II 44: 1623-1644

Gowing MM, Garrison DL, Gibson AH, Krupp JM, Jeffries $\mathrm{MO}$, Fritsen $\mathrm{CH}$ (2004) Bacterial and viral abundance in Ross Sea summer pack ice communities. Mar Ecol Prog Ser 279:3-12

Gradinger R (1999) Integrated abundance and biomass of sympagic meiofauna in Arctic and Antarctic pack ice. Polar Biol 22:169-177

Hong Y, Smith WO Jr, White AM (1997) Studies on transparent exopolymer particles (TEP) produced in the Ross Sea (Antarctica) and by Phaeocystis antarctica (Prymnesiophyceae). J Phycol 33:368-376

Horner R (1985) Ecology of sea ice microalgae. In: Horner R (ed) Sea ice biota. CRC Press, Boca Raton, FL, p 83-103

Horner R, Schrader GC (1982) Relative contributions of ice algae, phytoplankton, and benthic microalgae to primary production in nearshore regions of the Beaufort Sea. Arctic 35:485-503

Krembs C, Engel A (2001) Abundance and variability of microorganisms and transparent exopolymer particles across the ice-water interface of melting first-year sea ice in the Laptev Sea (Arctic). Mar Biol 138:173-185

Krembs C, Eicken H, Junge K, Deming JW (2002) High concentrations of exopolymeric substances in Arctic winter sea ice: implications for polar ocean carbon cycle and cryoprotection of diatoms. Deep-Sea Res I 49:2163-2181

Legendre L, Ackley SF, Dieckmann GS, Gulliksen B and 6 others (1992) Ecology of sea ice biota. 2. Global significance. Polar Biol 12:429-444

Mancuso Nichols CA, Garon S, Bowman JP, Raguenes G, Guezennec J (2004) Production of exopolysaccharides by Antarctic marine bacterial isolates. J Appl Microbiol 96:1057-1066

Mancuso Nichols CA, Guezennec J, Bowman JP (2005) Bacterial exopolysaccharides from extreme marine environments with special consideration of the southern ocean, sea ice and deep-sea hydrothermal vents: a review. Mar Biotechnol 7:253-271

Maranger R, Bird DF, Juniper SK (1994) Viral and bacterial dynamics in Arctic sea ice during the spring algal bloom near Resolute, N.W.T., Canada. Mar Ecol Prog Ser 111: $121-127$

Mari X (1999) Carbon content and C:N ratio of transparent exopolymeric particles (TEP) produced by bubbling exudates of diatoms. Mar Ecol Prog Ser 183:59-71

Meiners K, Gradinger R, Fehling J, Civitarese G, Spindler M (2003) Vertical distribution of exopolymer particles in sea ice of the Fram Strait (Arctic) during autumn. Mar Ecol Prog Ser 248:1-13

Meiners K, Brinkmeyer R, Granskog MA, Lindfors A (2004) Abundance, size distribution and bacterial colonization of exopolymer particles in Antarctic sea ice (Bellingshausen Sea). Aquat Microb Ecol 35:283-296

Melnikov IA, Kolosova EG, Welch HE, Zhitina LS (2002) Sea ice biological communities and nutrient dynamics in the Canada Basin of the Arctic Ocean. Deep-Sea Res I 49: 1623-1649

Michel C, Legendre L, Ingram RG, Gosselin M, Levasseur M (1996) Carbon budget of sea-ice algae in spring: evidence of a significant transfer to zooplankton grazers. J Geophys Res 101:18345-18360

Michel C, Nielsen TG, Nozais C, Gosselin M (2002) Significance of sedimentation and grazing by ice micro- and 
meiofauna for carbon cycling in annual sea ice (northern Baffin Bay). Aquat Microb Ecol 30:57-68

Myklestad SM (1995) Release of extracellular products by phytoplankton with special emphasis on polysaccharides. Sci Total Environ 165:155-164

Nozais C, Gosselin M, Michel C, Tita G (2001) Abundance, biomass, composition and grazing impact of the sea-ice meiofauna in the North Water, northern Baffin Bay. Mar Ecol Prog Ser 217:235-250

Parsons TR, Maita Y, Lalli CM (1984) A manual of chemical and biological methods for seawater analysis. Pergamon Press, Toronto

Passow U (2000) Formation of transparent exopolymer particles, TEP, from dissolved precursor material. Mar Ecol Prog Ser 192:1-11

Passow U (2002a) Transparent exopolymer particles (TEP) in aquatic environments. Prog Oceanogr 55:287-333

Passow U (2002b) Production of transparent exopolymer particles (TEP) by phyto- and bacterioplankton. Mar Ecol Prog Ser 236:1-12

Passow U, Alldredge AL (1994) Distribution, size and bacterial colonization of transparent exopolymer particles (TEP) in the ocean. Mar Ecol Prog Ser 113:185-198

Passow U, Alldredge AL (1995) A dye-binding assay for the spectrophotometric measurement of transparent exopolymer particles (TEP). Limnol Oceanogr 40:1326-1335

Passow U, Shipe RF, Murray A, Pak DK, Brzezinski MA, Alldredge AL (2001) The origin of transparent exopolymer particles (TEP) and their role in the sedimentation of particulate matter. Cont Shelf Res 21:327-346

Ramaiah N, Yoshikawa T, Furuya K (2001) Temporal variations in transparent exopolymer particles (TEP) associated with a diatom spring bloom in a subarctic ria in Japan. Mar Ecol Prog Ser 212:79-88

Rysgaard S, Kuhl M, Glud RN, Würgler Hansen J (2001) Biomass, production and horizontal patchiness of sea ice algae in a high-Arctic fjord (Young Sound, NE Greenland). Mar Ecol Prog Ser 223:15-26

Salcher MM, Pernthaler J, Psenner R, Posch T (2005) Succession of bacterial grazing defense mechanisms against protistan predators in an experimental microbial community. Aquat Microb Ecol 38:215-229

Schuster S, Herndl GJ (1995) Formation and significance

Editorial responsibility: Edna Granéli,

Kalmar, Sweden of transparent exopolymeric particles in the northern Adriatic Sea. Mar Ecol Prog Ser 124:227-236

Sherr EB, Caron DA, Sherr BF (1993) Staining of heterotrophic protists for visualization via epifluorescence microscopy. In: Kemp PF, Sherr BF, Sherr EB, Cole JJ (eds) Handbook of methods in aquatic microbial ecology. Lewis Publications, Boca Raton, FL, p 213-227

Simon M, Grossart HP, Schweitzer B, Ploug H (2002) Microbial ecology of organic aggregates in aquatic ecosystems. Aquat Microb Ecol 28:175-211

Smith DJ, Underwood GJC (1998) Exopolymer production by intertidal epipelic diatoms. Limnol Oceanogr 43: 1578-1591

Smith REH, Harrison WG, Harris LR, Herman AW (1990) Vertical fine structure of particulate matter and nutrients in sea ice of the high Arctic. Can J Fish Aquat Sci 47:1348-1355

Smith REH, Gosselin M, Taguchi S (1997) The influence of major inorganic nutrients on the growth and physiology of high arctic ice algae. J Mar Syst 11:63-70

Sokal RR, Rohlf FJ (1995) Biometry: the principles and practice of statistics in biological research, 3rd edn. WH Freeman, New York

Stoderegger KE, Herndl GJ (1999) Production of exopolymer particles by marine bacterioplankton under contrasting turbulence conditions. Mar Ecol Prog Ser 189:9-16

Thornton DCO (2002) Diatom aggregation in the sea: mechanisms and ecological implications. Eur J Phycol 37:149-161

Turner JT (2002) Zooplankton fecal pellets, marine snow and sinking phytoplankton blooms. Aquat Microb Ecol 27: 57-102

Underwood GJC, Paterson DM, Parkes RJ (1995) The measurement of microbial carbohydrate exopolymers from intertidal sediments. Limnol Oceanogr 40:1243-1253

Urbani R, Magaletti E, Sist P, Cicero AM (2005) Extracellular carbohydrates released by the marine diatoms Cylindrotheca closterium, Thalassiosira pseudonana and Skeletonema costatum: effects of P-depletion and growth status. Sci Total Environ 353:300-306

Waite AM, Olson RJ, Dam HG, Passow U (1995) Sugarcontaining compounds on the cell surfaces of marine diatoms measured using concanavlin $\mathrm{A}$ and flow cytometry. J Phycol 31:925-933

Submitted: March 21, 2006; Accepted: August 9, 2006

Proofs received from author(s): November 3, 2006 